\title{
ANALISIS CITRA GINJAL UNTUK IDENTIFIKASI SEL PIKNOSIS DAN SEL NEKROSIS
}

\section{Oleh:}

\author{
Ajeng Silvia Puji Lestari ${ }^{1}$, Agus Mulyono ${ }^{2}$
}

\begin{abstract}
ABSTRAK : Ginjal adalah organ yang mengatur komposisi kimia dari lingkungan dalam, melalui suatu proses majemuk yang melibatkan filtrasi, absorpsi aktif, absorpsi pasif dan sekresi. Selain itu ginjal juga mengatur tekanan darah dan volume darah dalam tubuh. Seperti halnya hati, ginjal juga rawan terhadap zat-zat kimia. Oleh karena itu, zat kimia yang terlalu banyak berada di dalam ginjal diduga akan mengakibatkan kerusakan sel, seperti piknosis dan Nekrosis. Piknosis atau pengerutan inti merupakan homogenisasi sitoplasma dan peningkatan eosinofil. Sedangkan Nekrosis merupakan kematian sel jaringan akibat jejas saat individu masih hidup. Pada penelitian di bidang biologi, dalam menentukan sil piknosis dan nekrosis umumnya mereka masih mengira-ngira dan masih menggunakan perhitungan secara manual sehingga data yang dihasilkan memiliki nilai eror yang relatif tinggi, karena sangat tipisnya perbedaan dari ciri sel-sel tersebut dan perbedaan persepsi setiap orang dalam melihat dan menghitung jumlah sel piknosis dan nekrosis. Untuk mengatasi hal tersebut diperlukan suatu pemikiran serta inovasi teknologi praktis tepat guna untuk mempermudah dalam penghitungan sel-sel tersebut. Berdasarkan latar belakang tersebut penelitian dilakukan dengan tujuan: (1) Mencari nilai threshold yang tepat untuk identifikasi sel piknosis dan nekrosis. (2) Mencari ketepatan program aplikasi yang digunakan dalam penghitungan jumlah sel.

Penelitian ini menggunakan metode eksperimental dalam bentuk pengolahan citra digital, dimana objek penelitiannya berupa citra digital. Pengolahan citra dilakukan dengan mengubah warna citra menjadi grayscale dan selanjutnya menapis citra menggunakan filter Gaussian dan dilanjutkan dengan mencari nilai threshold yang tepat untuk menentukan ciri dari masing-masing sel piknosis dan nekrosis.

Nilai threshold yang didapatkan dari penelitian ini yaitu $0.66,0.67,0.68$. Nilai yang paling tepat untuk mencirikan sel piknosis dan nekrosis adalah nilai threshold 0.67 , selanjutnya citra hasil threshold ditest dengan aplikasi penghitungan sel dan mendapatkan hasil yang cukup memuaskan yaitu dengan nilai KR (Kesalahan Relatif) masing-masing sel (sel piknosis dan sel nekrosis) adalah $8.5 \%$ dan $9 \%$.
\end{abstract}

Kata Kunci: Ginjal, Pengolahan Citra Digital, Threshold.

\section{PENDAHULUAN}

Ginjal adalah organ yang mengatur komposisi kimia dari lingkungan dalam, melalui suatu proses majemuk yang melibatkan filtrasi, absorpsi aktif, absorpsi pasif dan sekresi. Selain itu ginjal juga mengatur tekanan darah dan volume darah dalam tubuh. Seperti halnya hati, ginjal juga rawan terhadap zat-zat kimia. Oleh karena itu, zat kimia yang terlalu banyak berada di dalam ginjal diduga akan mengakibatkan kerusakan sel, seperti piknosis dan Nekrosis. Piknosis atau pengerutan inti merupakan homogenisasi sitoplasma dan peningkatan eosinofil. Sedangkan Nekrosis merupakan kematian sel jaringan akibat jejas saat individu masih hidup. Pada penelitian di bidang biologi, dalam menentukan sil

1,2 Jurusan Fisika,F-Siantek UIN Maliki Malang Alamat Koresponden (E-mail: king.8girl@gmail.com)

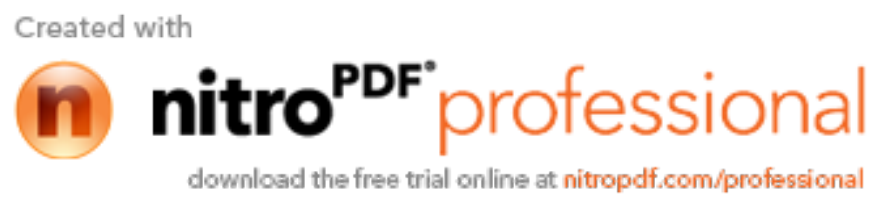


piknosis dan nekrosis umumnya mereka masih mengira-ngira dan masih menggunakan perhitungan secara manual sehingga data yang dihasilkan memiliki nilai eror yang relatif tinggi, karena sangat tipisnya perbedaan dari ciri sel-sel tersebut dan perbedaan persepsi setiap orang dalam melihat dan menghitung jumlah sel piknosis dan nekrosis. Untuk mengatasi hal tersebut diperlukan suatu pemikiran serta inovasi teknologi praktis tepat guna untuk mempermudah dalam penghitungan sel-sel tersebut.

Penelitian ini bertujuan: (1) Mencari nilai threshold yang tepat untuk identifikasi sel piknosis dan nekrosis. (2) Mencari ketepatan program aplikasi yang digunakan dalam penghitungan jumlah sel.

\section{KAJIAN TEORI}

Ginjal adalah organ yang mengatur komposisi kimia dari lingkungan dalam, melalui suatu proses majemuk yang melibatkan filtrasi, absorpsi aktif, absorpsi pasif dan sekresi. Selain itu ginjal juga mengatur tekanan darah dan volume darah dalam tubuh. Ginjal terletak pada dinding posterior abdomen terutama di daerah lumbal, disebelah kanan dan kiri tulang belakang dibungkus lapisan lemak, dibelakang peritorium (Price \& Wilson, 1995).

Glomerulus adalah suatu organ epitelio-vaskuler yang dirancang untuk filtrasi ultra dari plasma. Kapiler glomerulus dilapisi oleh lapisan endotelium, berlubang pori-pori dengan diameter kurang lebih $100 \mathrm{~nm}$ dan terletak pada membrana basalis.

Piknosis atau pengerutan inti merupakan homogenisasi sitoplasma dan peningkatan eosinofil. Piknosis ini merupakan tahap awal kematian sel (nekrosis). Nekrosis merupakan kematian sel jaringan akibat jejas saat individu masih hidup.

Untuk menentukan sel piknosis dan sel nekrosis menggunakan pengolahan citra. Pengolahan citra merupakan proses pengolahan dan analisis citra yang banyak melibatkan persepsi visual. Proses ini mempunyai ciri data masukan dan informasi keluaran yang berbentuk citra. Namun citra yang dihasilkan dari proses pengolahan citra memiliki kualitas yang lebih baik dibandingkan dengan citra aslinya.

Konsep greyscale adalah mengubah tiga layer tersebut menjadi satu layer matriks greyscale, yang menghasilkan satu citra greyscale. Di dalam citra ini tidak ada lagi warna, yang ada adalah derajat keabuan.

Thresholding digunakan untuk mengatur jumlah derajat keabuan yang ada pada citra. Proses thresholding ini pada dasarnya adalah proses penggubahan kuantisasi pada citra. Untuk mendapatkan hasil segmentasi yang bagus, beberapa operasi perbaikan kualitas citra dilakukan terlabih dahulu untuk mempertajam batas antara objek dengan latar belakangnya (Usman, 2005: 81).

\section{METODE PENELITIAN}

Alat yang digunakan pada penelitian ini terdiri atas Sampel ginjal (mencit), P.C dengan Software MATLAB 7.0. dan Delhi 7. Identifikasi dilakukan dengan Pengolahan Citra (pre processing) yang meliputi: Pemotongan (cropping), penapisan, Mengubah warna citra kedalam grayscale (keabuan). 
Penelitian ini menggunakan analisis Citra yang pertama yaitu Konversi citra ke biner ini bertujuan untuk mendapatkan 2 kemungkinan nilai yaitu nol dan satu yang sehingga memudahkan dalam pencarian nilai threshold. Selanjutnya histogram dimana bisa diketahui pola dari derajat keabuan sebuah citra, oleh karena itu dalam setiap citra pasti terdapat perbedaan dalam histogramnya yang mana bisa dijadikan ciri citra. Kemudian mencari nilai batas ambang (Threshold), Thresholding digunakan untuk mengatur jumlah derajat keabuan yang ada pada citra. Dimana dalam penelitian tentang analisis citra ginjal untuk identifikasi sel piknosis dan nekrosis ini nilai tresholding ditujukan untuk membatasi masing masing sel, sehingga dapat terklasifikasi antara sel piknosis dan nekrosis. Nilai tresholding didapat dari eksperimen dari ciri ciri yang didapat. Proses thresholding ini pada dasarnya adalah proses pengubahan kuantisasi pada citra.

\section{HASIL DAN PEMBAHASAN \\ Hasil Penelitian \\ Hasil Analisis Sampel}

Citra ginjal adalah citra yang diperoleh dari mikroskop inverted. Kualitas alat untuk mengambil citra ginjal sangat mempengaruhi dalam penelitian ini, pengambilan citra dengan kamera digital akan menghasilkan citra dengan resolusi atau kecerahan berubahubah karena pada kamera digital tidak ada pengaturan resolusi yang tetap, selain itu pada kamera digital tempat atau posisi pengambilan citra tidak bisa tetap atau sama sehingga antara data citra pertama dengan citra kedua bisa berbeda-beda tingkat kecerahan dan besar kecilnya citra, sehingga dapat mempengaruhi waktu pengolahan data. Perbedaan antara pengambilan citra menggunakan kamera digital dan mikroskop inverted ditunjukkan pada gambar 1 .

A. Kamera Digital

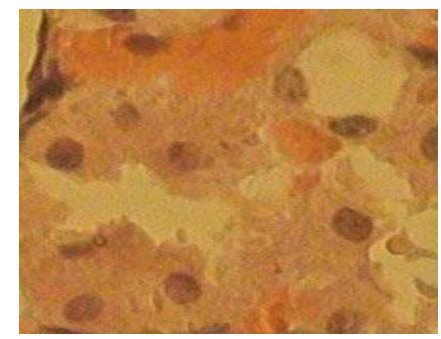

B. Mikroskop inverted

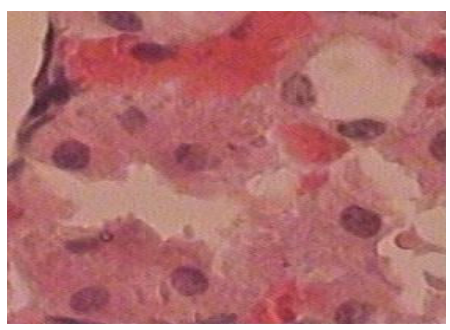

Gambar 1. Pengambilan citra Ginjal menggunakan kamera digital dan mikroskop inverted

Mikroskop inverted yang dipakai menggunakan tingkat kecahayaan 3.5 dan perbesaran 400X. Hasil dari mikroskop inverted adalah citra Ginjal dengan ukuran $760 \times 570$ dan kemudian di-crop dengan ukuran 226x221 pada bagian tubulus proksimalis yang teridentifikasi kerusakan se dan dalam pengambilan sampel menggunakan pewarnaan He (Hemoxtosilin aosin)l.

Sebelum dilakukan analisis nilai threshold, terlebih dahulu citra dilakukan perbaikan citra yaitu dengan tahapan tahapan sebagai berikut: Pertama Dengan 
menggunakan pengubah representasi nilai RGB (Red, Green, Blue), sebuah gambar berwarna dapat diubah menjadi gambar yang terdiri dari warna putih dan gradiasi warna hitam yang biasanya disebut gambar greyscale. Untuk mengubah RGB menjadi greyscale dapat digunakan rumus sebagai berikut (Gonzales, Wood , 1987):

$$
\text { grayscale }=0.299 \mathrm{R}+0.587 \mathrm{G}+
$$

\section{$0.114 \mathrm{~B}$}

atau

$$
\text { grayscal }=0.333 \mathrm{R}+0.333 \mathrm{G}+0.333 \mathrm{~B}
$$

Perhitungan nilai grayscale yang sebenarnya adalah dengan menggunakan persamaan 2.2, namun persamaan yang umum digunakan adalah persamaan 2.3 karena lebih mudah untuk digunakan dan diingat (Gonzales, dkk , 1987).

Karena citra tubulus memiliki warna yang dominan yaitu warna merah, sehingga untuk menggubah menjadi grayscale hanya dengan melakukan pemanggilan citra berwarna merah yang kemudian dengan pemanggilan citra warna merah tersebut, citra ginjal keluar sebagai citra graiscale, dengan listing program matlab:

Red=I( :, :, 1 ), sehingga menghasilkan citra grayscale sebagai berikut:

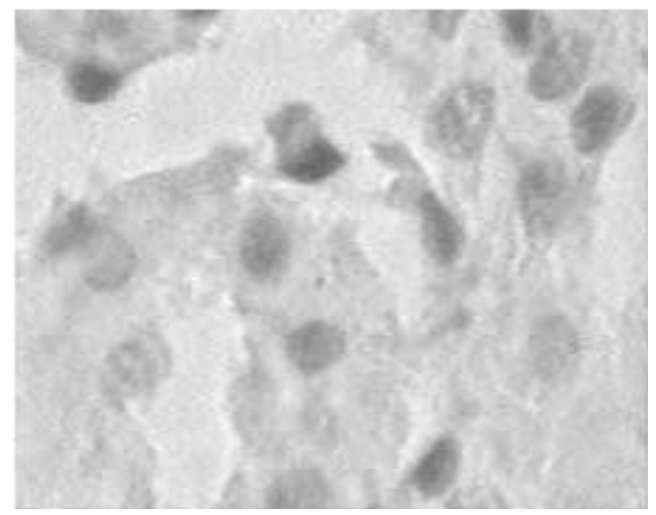

Gambar 2. pemanggilan citra red pada citra tubulus

Kedua yaitu citra grayscale dilakukan penapisan yaitu menggunakan filter mean dengan maksud membuat samar atau blur seluruh citra sehingga saat dilakukan langkah berikutnya yaitu pencariaan nilai threshold, citra dapat disisakan hanya pada sel matinya saja. Dengan listing program matlab:

meanFilter $=$ fspecial('average', 5)

Filter fspacial dapat menghasilkan sebuah filter perata-rata. Tipe filter ini menghitung nilai keluaran dari sebuah pixel keluaran dengan merata ratakan nilai dari pixel tetangganya( sekelilingnya)(Ch.Wijaya Marvin \& Prijon agus.2007).

Rumus filter mean yaitu (http://www.scribd.com/doc/57637448/MenghilangkanDerau-Citra-Additive-Dengan-Filter-Mean-Spatial-Filtering diakses pada tanggal 25 Juni 2011 at 23:08):

$$
f(x, y)-\frac{1}{m n} \Sigma_{(s t i s x y} g(s, t)
$$


$\mathrm{g}(\mathrm{s}, \mathrm{t})$ adalah citra yang akan difilter, Sxy adalah subimage atau daerah yang dikenai oleh jendela, , $f(x, y)$ adalah nilai intensitas setelah difilter, sedangkan $m$ dan $n$ merupakan baris dan kolom sebuah matrik filter, yang biasanya matrik ini berukuran ganjil x ganjil agar ada poros tengah karena hasil perhitungan rerata akan diberikan pada titik tengah dari matriks yang dapat dilihat pada citra sampel yang memiliki matrik sebagai berikut:

Tabel 1. Matrik 3x3 sampel citra ginjal

\begin{tabular}{|c|c|c|}
\hline 0.082 & 0.039 & 0.011 \\
\hline 0.287 & 0.135 & 0.039 \\
\hline 0.606 & 0.287 & 0.082 \\
\hline
\end{tabular}

Tabel 1 adalah tabel matriks $3 \times 3$ yang memiliki nilai matriks pada 1,1( dibaca matriks kolom 1 dan baris 1); 1,2 (dibaca matriks kolom 1 dan baris 2); 1,3 (dibaca matriks kolom 1 dan baris 3 ) berturut turut adalah 0.082; 0.039; 0.011 ,nilai matriks pada 2,1 (dibaca matriks kolom 2 dan baris 1); 2,2 (dibaca matriks kolom 2 dan baris 2); 2,3 (dibaca matriks kolom 2 dan baris 3 ) berturut turut 0.287; 0.135; 0.039 dan nilai matriks pada 3,1 (dibaca matriks kolom 3 dan baris 1); 3,2 (dibaca matriks kolom 3 dan baris 2); 3,3 (dibaca matriks kolom 3 dan baris 3)

Untuk melihat matriks pada citra digunakan listring program sebagai berikut:

I=imread('nama file.jpg') dituliskan pada common window matlab, sehingga setelah matriks muncul pada common window dapat dihitung nilai hasil pemfilteran yaitu:

$$
\begin{aligned}
\text { hasil filter } & =\frac{1}{(3)(3)}(1.1+1.2+1.3+2.1+2.2+2.3+3.1+3.2+3.3) \\
& =\frac{1}{(2)(3)}(0.082+0.039+0.011+0.287+0.135+0.039+0.606+0.287+0.082) \\
& =\frac{1}{9}(1.568) \\
& =0.174
\end{aligned}
$$

Sehingga keluaran matrik yang dihasilkan adalah: 
Tabel 2. Matrik 3x3 hasil dari filter median

\begin{tabular}{|l|l|l|}
\hline 0.082 & 0.039 & 0.011 \\
\hline 0.287 & 0.174 & 0.039 \\
\hline 0.606 & 0.287 & 0.082 \\
\hline
\end{tabular}

Dan citra yang dihasilkan yaitu sebagai berikut:

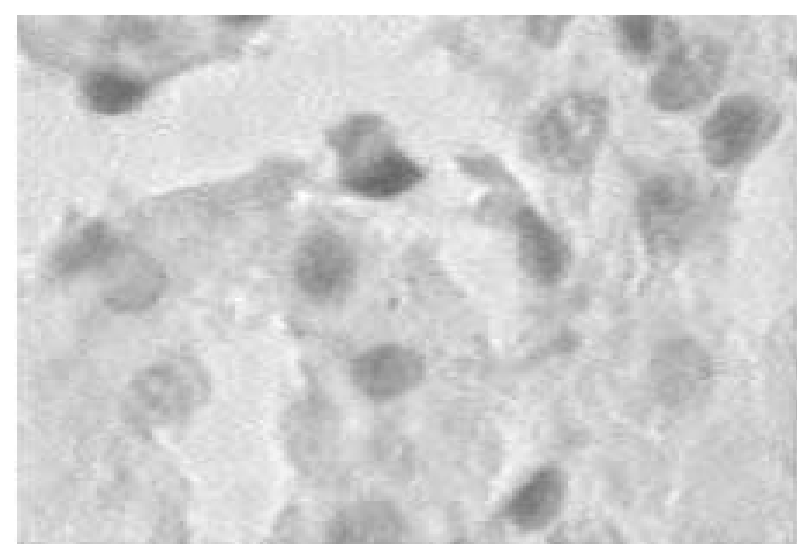

Gambar 3. hasil citra filter mean

Akan tetapi filter mean ini tidak cukup mampu untuk memisahkan sel sel dari latar belakang yang banyak sebaran noise-nya, yang kemudian digunakan filter gausian untuk mengatasi hal tersebut. Dengan listing program:

Gaussian Filter $=$ fspecial('gaussian', [2, 2], 5)

Sama halnya dengan filter mean, filter Gaussian juga menggunakan fspecial yang menghasilkan filter perata-rata dengan rumusan sebagai berikut (ahmad usman,2005):

$$
g(x, y)=c e^{\frac{\left(x^{2} 1 y^{2}\right)}{2 \sigma^{2}}}
$$

Dimana c konstanta normalisasi

Sehingga :

$$
\frac{g(x, y)}{\kappa}=\mathrm{e}^{\frac{\left(x^{2}+y^{2}\right)}{z \sigma^{2}}}
$$

Dengan menentukan nilai untuk $\sigma^{2}$, nilai-nilai pembobot untuk jendela nxn dapat dihitung menggunakan matriks diamana nilai pada $(0,0)$ adalah satu. Sebagai contoh, diambil $\sigma^{2}=2$ dengan $n=7$, persamaan diatas menghasilkan matrik sebagai 
Tabel 3. Matrik 7x7 sampel citra ginjal

\begin{tabular}{|l|l|l|l|l|l|l|l|}
\hline$(\mathrm{m}, \mathrm{n})$ & -3 & -2 & -1 & 0 & 1 & 2 & 3 \\
\hline-3 & 0.001 & 0.039 & 0.082 & 0.105 & 0.082 & 0.039 & 0.011 \\
\hline-2 & 0.039 & 0.135 & 0.287 & 0.368 & 0.287 & 0.135 & 0.039 \\
\hline-1 & 0.082 & 0.287 & 0.606 & 0.0 .779 & 0.606 & 0.287 & 0.082 \\
\hline 0 & 0.105 & 0.368 & 0.779 & 1.000 & 0.779 & 0.368 & 0.105 \\
\hline 1 & 0.082 & 0.287 & 0.606 & 0.779 & 0.606 & 0.287 & 0.082 \\
\hline 2 & 0.039 & 0.135 & 0.287 & 0.368 & 0.287 & 0.135 & 0.039 \\
\hline 3 & 0.011 & 0.039 & 0.082 & 0.105 & 0.082 & 0.039 & 0.011 \\
\hline
\end{tabular}

Tabel 3. adalah sebuah tabel matrik $7 \times 7$ dengan $m$ adalah jumlah kolom dan $n$ adalah jumlah baris dari matrik. Matrik $7 \times 7$ ini memiliki titik tengah yaitu pada matrik $(0,0)$. Untuk memudahkan mengetahui poros / titik tengah dari matrik maka disimbulkan dengan simbul $-3,-2,-1,0,1,2,3,4$.

Dari matrik diatas dapat dihitung filter Gaussian sebagai berikut:

$$
\frac{g(3,3)}{k}=e^{\frac{\left(3^{2} \wedge 3^{2}\right)}{2(2)^{2}}}=0.011=>k=\frac{g(0,0)}{0.11}=\frac{1}{0.011}=91
$$

Sehingga matrik dapat dikalikan dengan nilai konstanta $\mathrm{k}$ dan menghasilkan persebebaran menyeluruh dalam citra sebagai berikut:

Tabel 4. matrik 7x7 hasil filter Gaussian

\begin{tabular}{|l|l|l|l|l|l|l|l|}
\hline$(\mathrm{m}, \mathrm{n})$ & -3 & -2 & -1 & 0 & 1 & 2 & 3 \\
\hline-3 & 1 & 4 & 7 & 10 & 7 & 4 & 1 \\
\hline-2 & 4 & 12 & 26 & 33 & 26 & 12 & 4 \\
\hline-1 & 7 & 26 & 55 & 71 & 55 & 26 & 7 \\
\hline 0 & 10 & 33 & 71 & 91 & 71 & 33 & 10 \\
\hline 1 & 7 & 10 & 33 & 71 & 33 & 10 & 7 \\
\hline 2 & 4 & 7 & 10 & 3 & 10 & 7 & 4 \\
\hline 3 & 1 & 4 & 7 & 10 & 7 & 4 & 1 \\
\hline
\end{tabular}


Dan citra yang dihasilkan sebagai berikut:

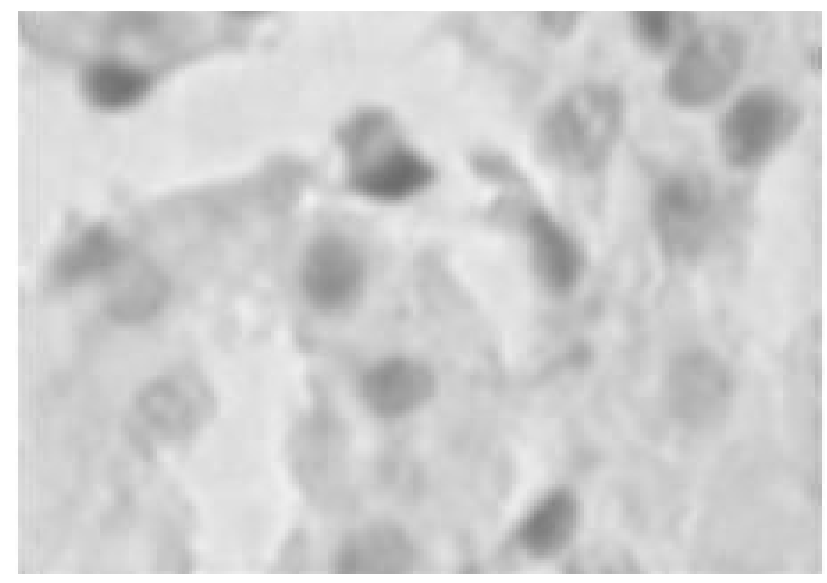

Gambar 4. Hasil citra filter Gaussian

Selanjutnya citra dianalisis nilai threshold -nya dengan memperhatikan ciri khas sel piknosis dan nekrosis itu sendiri. Sel piknosis dan sel nekrosis memiliki identifikasi sebagai berikut (Himawan, 1992):

Tabel 5. ciri sel piknosis dan nekrosis

\begin{tabular}{|l|l|}
\hline Sel Piknosis & Sel Nekrosis \\
\hline Nukleus terlihat lebih bundar & Hilangnya gambaran kromatin \\
\hline Ukuran lebih kecil & Inti menjadi keriput \\
\hline Warnanya gelap & Inti tampak lebih padat \\
\hline & Warna lebih hitam \\
\hline & Inti terbagi menjadi fragmen-fragmen/robek \\
\hline
\end{tabular}

Sebagaimana ciri yang ada, yaitu gambaran inti sel nekrosis lebih gelap dibandingkan dari sel piknosis sehingga hasil pengolahan citra akan dianalisis nilai threshold (batas ambang) -nya dengan cara experimental untuk merumuskan ciri dari sel piknosis dan nekrosis secara komputerisasi menggunakan program Matlab 7.0, dengan list program

$\mathrm{BW}=\mathrm{im} 2 \mathrm{bw}($ hasil, 0.55);

figure, imshow (BW)

BW = im2bw(hasil, 0.56);

figure, imshow (BW)

BW = im2bw(hasil, 0.57);

figure, imshow (BW)

Dan dijabarkan pada tabel 6 dan 7 sebagai berikut: 
Tabel 6. hasil analisis nilai threshold pada sel piknosis

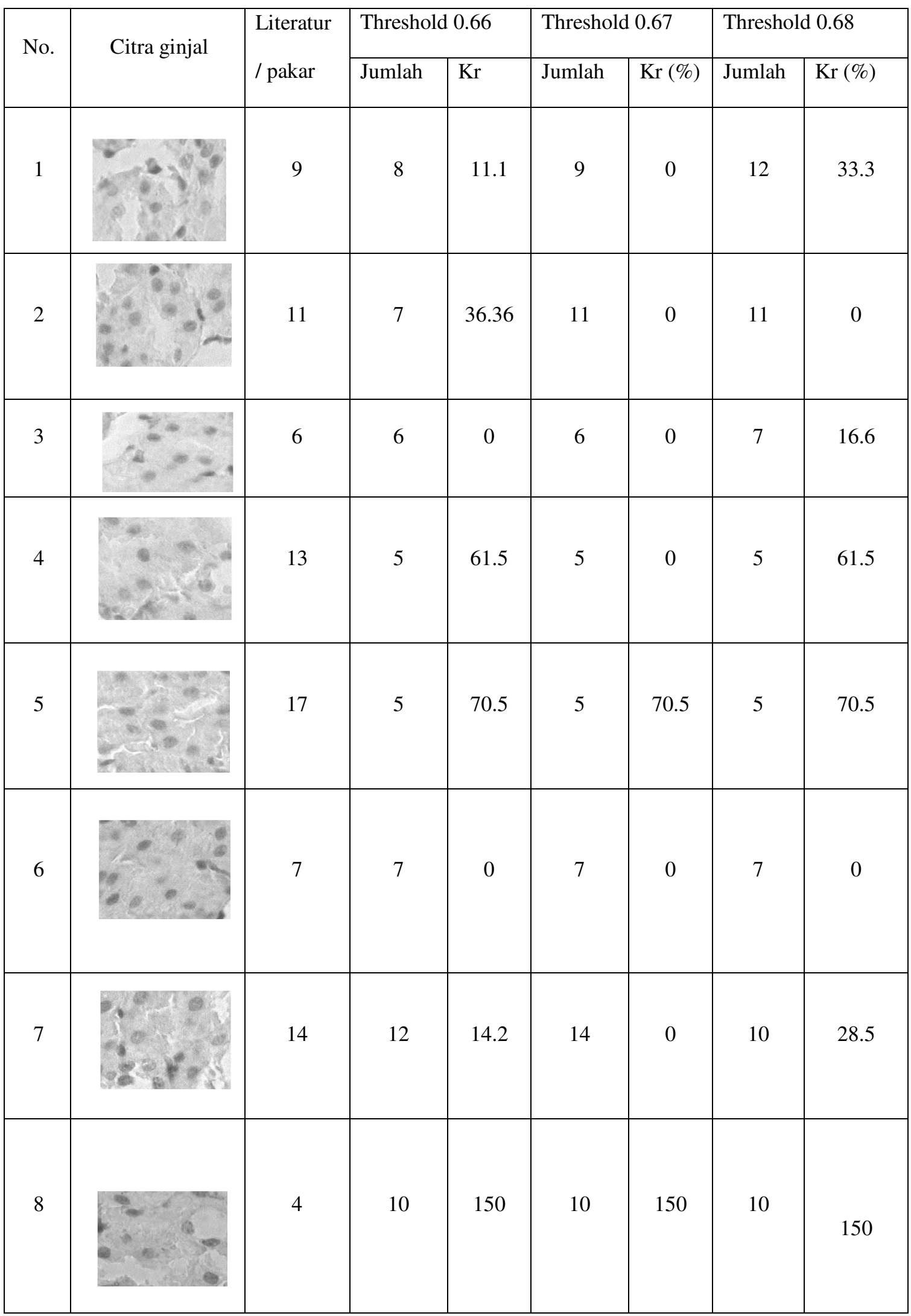

Created with 


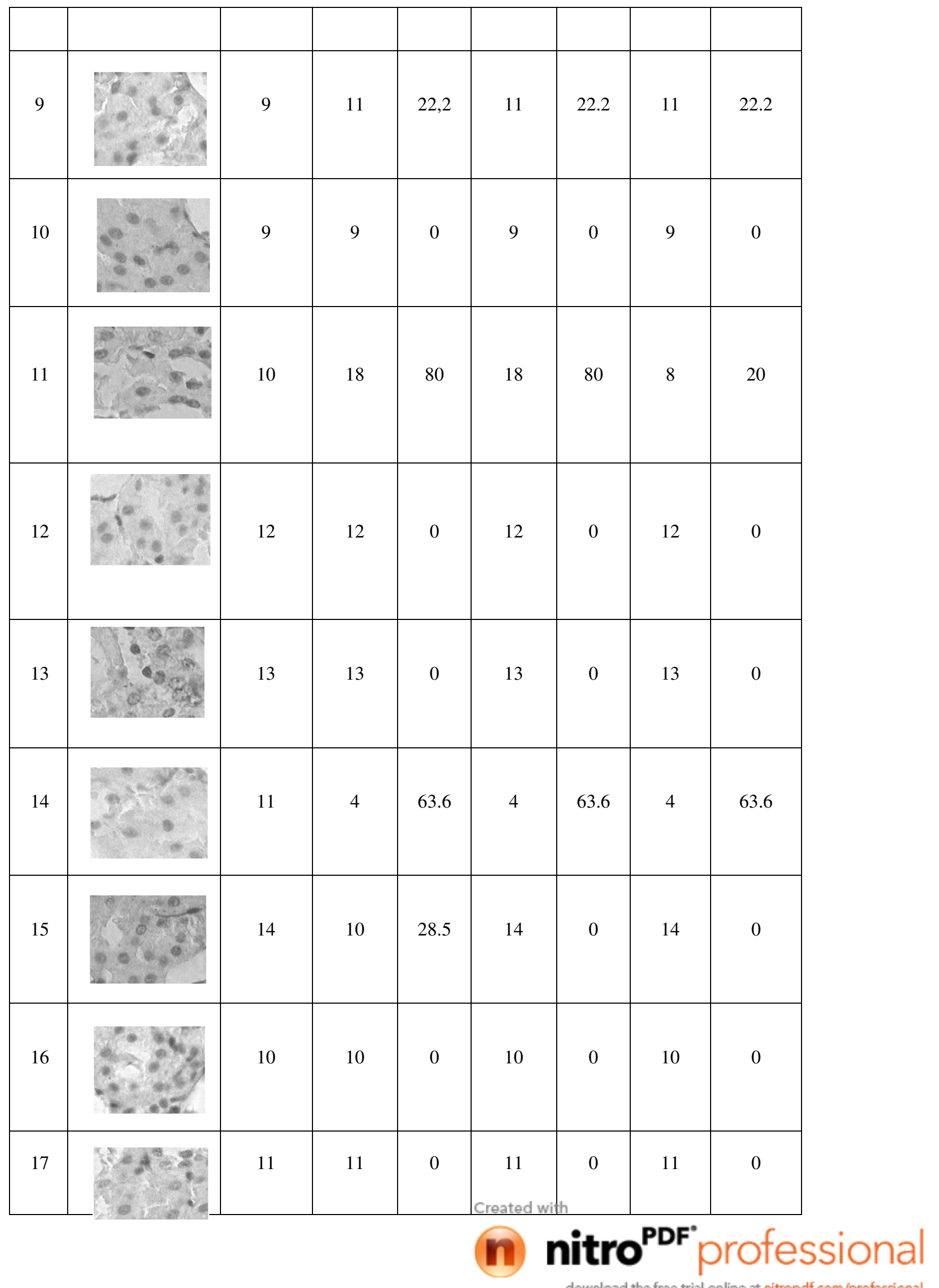




\begin{tabular}{|c|c|c|c|c|c|c|c|}
\hline 18 & & & & & & & \\
\hline & 6 & 6 & 0 & 6 & 0 & 6 & 0 \\
\hline 19 & 11 & 11 & 0 & 11 & 0 & 7 & 36.3 \\
\hline 20 & 11 & 11 & 0 & 11 & 0 & 11 & 0 \\
\hline \\
\hline
\end{tabular}

Tabel 6 adalah tabel yang menjelaskan tentang analisis jumlah sel nekrosis yang dikenali oleh aplikasi dengan menggunakan nilai threshold (batas ambang) mulai dari 0.66-0.68 dibandingkan dengan jumlah sel dari literature/pakar yang setiap masing masing sampel citra dihitung nilai KR (kesalahan relatif) yang dirumuskan dengan rumus:

$$
\mathrm{KR}=\frac{\text { jumlah sel Pakar-jumlah sal softwary }}{\text { jumlah sgl pakar }} X 100 \% \text { dengan satuan \% (persen) }
$$

Dari nilai KR tersebut dapat dilihat berapa persen prosentase kesalahan aplikasi dalam mengenali sel piknosis. Dan dari keseluruhan sampel didapatkan nilai KR rata rata yaitu dengan rumus:

KR rata-rata $=\frac{2: K R}{N}$ dengan satuan $\%$ (persen)

Yang masing masing KR ataupun KR rata rata dapat dilihat pada tabel 4.6 tersebut.

Tabel 7. Hasil analisis nilai threshold pada sel nekrosis

\begin{tabular}{|c|c|c|c|c|c|c|c|c|}
\hline \multirow{2}{*}{ No. } & \multirow{2}{*}{ Citra ginjal } & \multirow{2}{*}{$\begin{array}{c}\text { Literatur/ } \\
\text { pakar }\end{array}$} & \multicolumn{2}{|c|}{ Threshold 0.66} & \multicolumn{2}{|c|}{ Threshold 0.67} & \multicolumn{2}{|c|}{ Threshold 0.68} \\
\hline & & & Jumlah & $\operatorname{Kr}(\%)$ & Jumlah & $\mathrm{Kr}(\%)$ & Jumlah & $\mathrm{Kr}(\%)$ \\
\hline 1 & 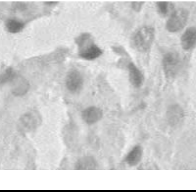 & 5 & 7 & 40 & Create & with & 5 & 0 \\
\hline
\end{tabular}




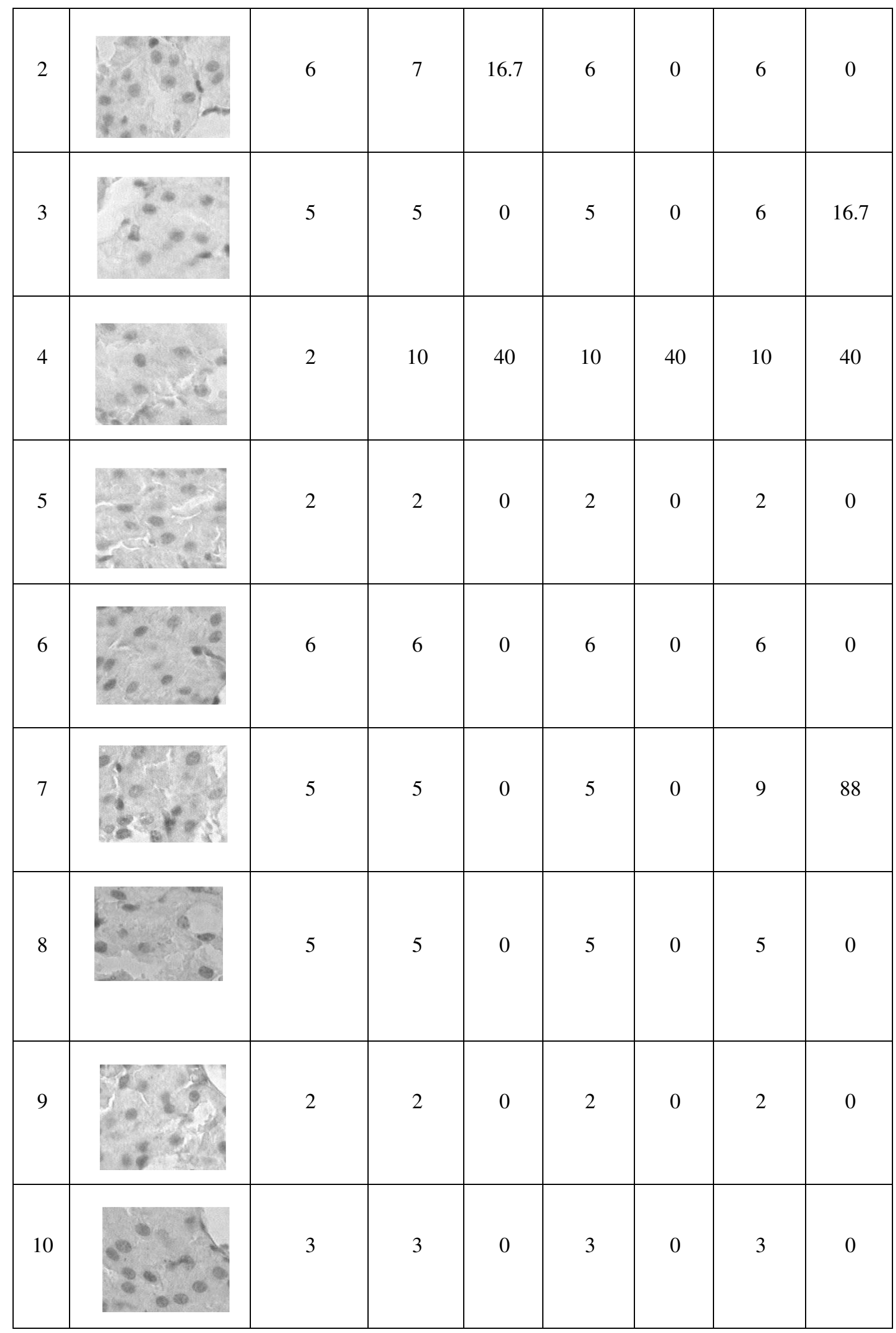

Created with 


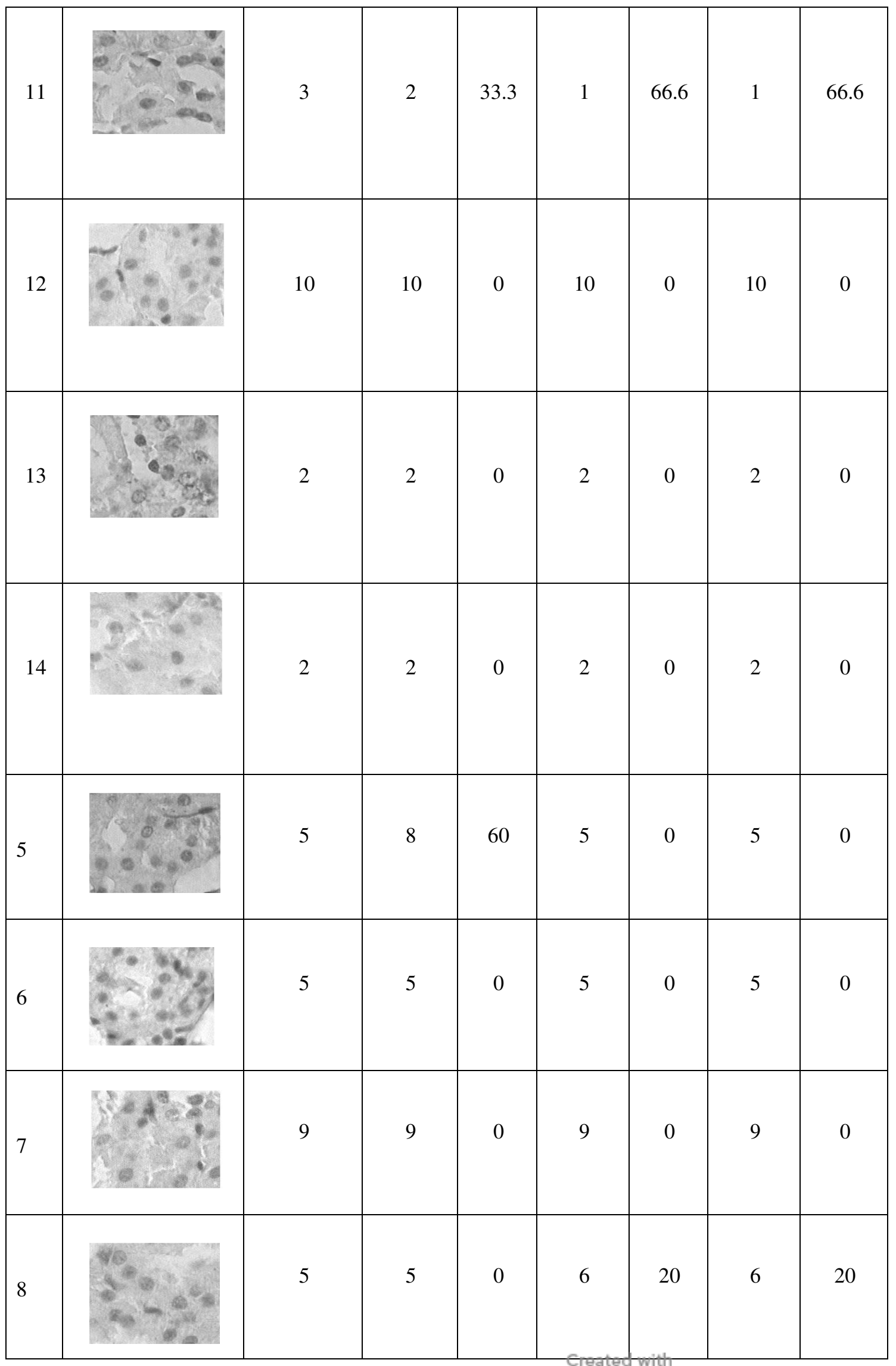




\begin{tabular}{|l|c|c|c|c|c|c|c|}
\hline 9 & 4 & 4 & 0 & 4 & 0 & 1 & 75 \\
\hline 0 & 1 & 1 & 0 & 1 & 0 & 1 & 0 \\
\hline \\
\hline
\end{tabular}

Tabel 7. adalah tabel yang menjelaskan tentang analisis jumlah sel nekrosis yang dikenali oleh aplikasi dengan menggunakan nilai threshold (batas ambang) mulai dari 0.66-0.68 dibandingkan dengan jumlah sel dari literature/pakar yang setiap masing masing sampel citra dihitung nilai KR (kesalahan relatif) yang dirumuskan dengan rumus:

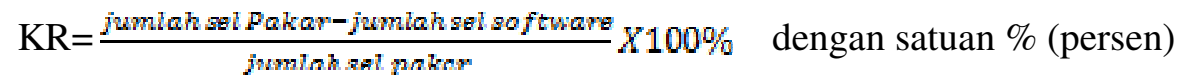

Dari nilai KR tersebut dapat dilihat berapa persen prosentase kesalahan aplikasi dalam mengenali sel nekrosis. Dan dari keseluruhan sampel didapatkan nilai KR rata rata yaitu dengan rumus:

KR rata-rata $=\frac{E K R}{N}$ dengan satuan $\%$ (persen)

Yang masing masing KR ataupun KR rata rata dapat dilihat pada tabel 6 tersebut.

Dari tabel 6 dan 7 dapat dibandingkan KR dari masing masing nilai threshold, Semakin kecil KR yang didapat maka Semakin besar kevalitan dari aplikasinya. Dan dapat dilihat dari tabal 6 dan 7 prosentase kesalahan relatif yang paling kecil yaitu terletak pada nilai threshold 0.67 dengan prosentase $\mathrm{Kr}$ yaitu $22.6 \%$ untuk sel piknosis dan $5.33 \%$ untuk sel nekrosis, untuk mendapatkan hasil yang memuaskan, akan dilakukan pengujian pada data sampel baru. Yang akan dibahas pada sub bab berikutnya.

\section{HASIL PENGUJIAN APLIKASI PROGRAM}

Pengujian aplikasi program dilakukan menggunakan data baru yaitu data yang tidak dilakukan analisis nilai threshold, yang bertujuan untuk mengetahui kemampuan aplikasi yang digunakan untuk mengenali data yang belum dianalisis nilai threshold-nya. Pengujian ini digunakan data sebanyak 10 data citra ginjal. Hasil pengenalan dari data baru ditunjukkan pada Tabel 4 berikut: 
Tabel 8. Hasil uji data baru

\begin{tabular}{|c|c|c|c|c|c|c|}
\hline \multirow{2}{*}{$\begin{array}{l}\text { No. } \\
\text { Uji }\end{array}$} & \multicolumn{2}{|c|}{ Jumlah (Target) } & \multicolumn{2}{|c|}{ Jumlah (Pengenalan) } & \multicolumn{2}{|c|}{ KR(Kesalahan Relatif) } \\
\hline & Piknosis & Nekrosis & Piknosis & Nekrosis & Piknosis & Nekrosis \\
\hline 1 & 14 & 5 & 14 & 5 & $0 \%$ & $0 \%$ \\
\hline 2 & 11 & 4 & 11 & 4 & $0 \%$ & $0 \%$ \\
\hline 3 & 6 & 5 & 6 & 5 & $0 \%$ & $0 \%$ \\
\hline 4 & 9 & 2 & 11 & 11 & $22.2 \%$ & $45 \%$ \\
\hline 5 & 11 & 2 & 4 & 11 & $63.6 \%$ & $45 \%$ \\
\hline 6 & 11 & 9 & 11 & 9 & $0 \%$ & $0 \%$ \\
\hline 7 & 9 & 3 & 9 & 3 & $0 \%$ & $0 \%$ \\
\hline 8 & 7 & 6 & 7 & 6 & $0 \%$ & $0 \%$ \\
\hline 9 & 11 & 1 & 11 & 1 & $0 \%$ & $0 \%$ \\
\hline 10 & 12 & 10 & 12 & 10 & $0 \%$ & $0 \%$ \\
\hline \multicolumn{5}{|c|}{ KR rata-rata $=\frac{2 K R}{N}$} & $8.58 \%$ & $9 \%$ \\
\hline
\end{tabular}

Dari tabel 8 dijelaskan pengenalan data baru oleh aplikasi, dari sampel no. 1 dapat dilihat target (literature/ahli) sel piknosis berjumlah 14 dan sel nekrosis berjumlah 5 dan dikenali oleh aplikasi dengan jumlah sel yang sama yaitu pada sel piknosis berjumlah 14 dan pada sel nekrosis berjumlah 5 sehingga dari sampel no 1 dapat dihitung nilai kesalahan relatif $(\mathrm{KR}=$ jumlah sel Pakar-jumlah sel sof twav $X) 1$

yaitu 0\%. dan hasil nilai KR yang sama ditunjukkan pada sampel no 2,3,6,7,8,9,10. Sedangkan pada sampel no 4 dari jumlah sel piknosis yang berjumlah 9 oleh aplikasi dikenali dengan jumlah 11 dan pada sel nekrosis yang berjumlah 2 pada aplikasi dikenali berjumlah 11, hal ini terjadi dikarenakan masih adanya noise (citra yang bukan sel piknosis / nekrosis) yang tidak mampu dinetralisasi oleh filter Gaussian dan juga disebabkan oleh proses pewarnaan sampel yang menggunakan pewarna HE (Hemaxtocylin Oesin) bekas pakai (rusak) yang mengakibatkan tidak terikatnya asam pada nucleus dan basa pada sitoplasma. Karena pada proses pengikatan asam dan basa dari pewarna HE itulah yang sangat berperan penting dalam pembentukan citra sel yang akan dihitung. Dimana Hematoksylin bekerja sebagai pewarna basa, artinya zat ini mewarnai unsur basofilik jaringan. Hematoksylin memulas inti dan strukutur asam lainnya dari sel (seperti bagian sitoplasma yang kaya-RNA dan matriks tulang rawan) menjadi biru.Eosin bersifat asam. Ia akan memulas komponen asidofilik jaringan seperti mitokondria, granula sekretoris dan kolagen. Tidak seperti hematoksilin, eosin mewarnai sitoplasma dan kolagen menjadi warna merah muda (Junquera, 2007).

Dan dalam pengujian data baru pada tabel 4.8 dengan menggunakan nilai threshold 0.67 mimiliki keberhasilan :

$$
\begin{gathered}
\% \text { Keberhasilan sel piknosis }=100 \%-K R \\
=100 \%-5.58 \%
\end{gathered}
$$




$$
\begin{aligned}
&=94.42 \% \\
& \% \text { Keberhasilan sel nekrosis }=100 \%-K R \\
&=100 \%-9 \% \\
&=91 \%
\end{aligned}
$$

\section{Hasil Tampilan Aplikasi Penghitungan Jumlah Sel Piknosis dan Nekrosis}

Aplikasi penghitungan jumlah sel piknosis dan nekrosis ini, mengunakan bahasa pemrograman delphi7, dan masih manual karena terpisah dengan pengolahan citranya yang menggunakan bahasa pemrograman matlab 7.0 karena keterbatasan dalam pengelink-an. Adapun aplikasinya memiliki 2 tampilan, yaitu tampilan aplikasi pengolahan citra digital dan aplikasi penghitungan jumlah sel piknosis dan nekrosis.

Aplikasi pengolahan citra terdiri dari menu bar file, "buka" yang berfungsi untuk membuka image dari drive tertentu, "simpan" berfungsi untuk menyimpan file, "keluar" berfungsi untuk keluar dari program dan "pengolahan" berfungsi untuk pengolahan citra. Dan pada Aplikasi penghitungan jumlah sel piknosis dan nekrosis tidak berbeda dengan menu menu bar pada aplikasi pengolahan citra yang terdiri dari beberapa menu bar yaitu file yang terdiri dari open picture, penghitungan, simpan dan keluar program. "Open picture" berfungsi untuk membuka image dari drive tertentu, "perhitungan" berfungsi untuk menghitung sel, "Simpan" berfungsi untuk menyimpan file, "Keluar Program" untuk keluar dari aplikasi. Serta menu menu tambahan seperti input training dan open training yang berfungsi untuk penyesuaian pengaturan aplikasi.

Adapun tampilan aplikasi pengolahan citra dan aplikasi penghitungan jumlah sel piknosis dan nekrosis dapat dilihat pada gambar 4.4 dan gambar 4.5 dibawah ini:

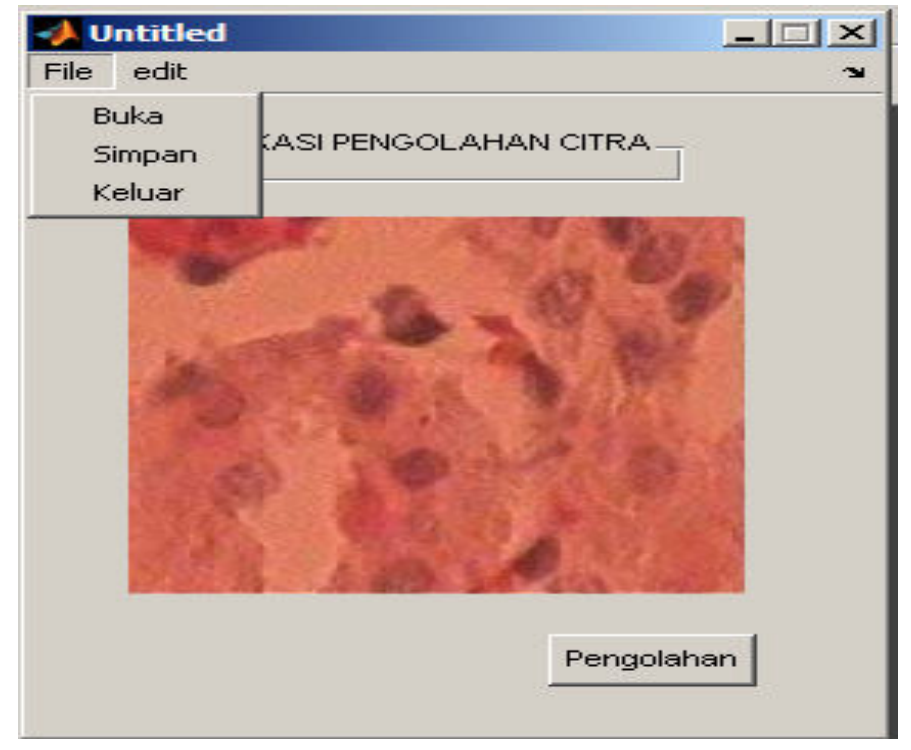

Gambar 5. Aplikasi pengolahan citra ginjal

\section{Created with}




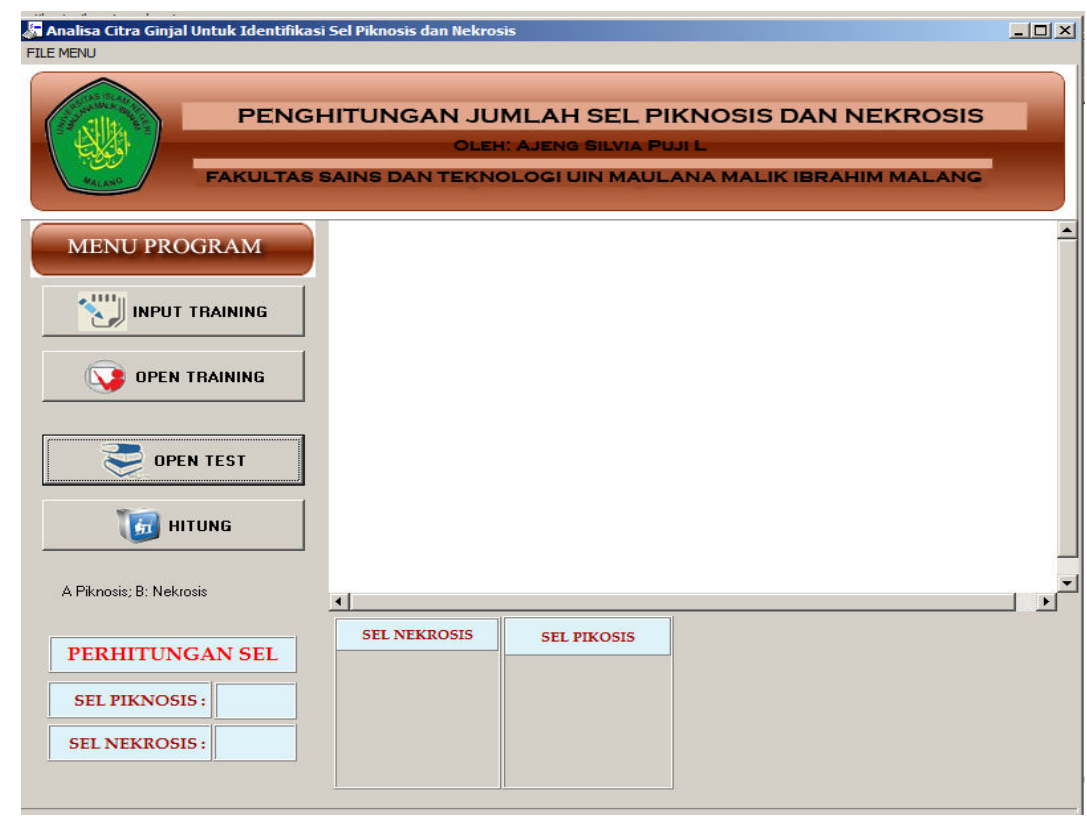

Gambar 6. Aplikasi penghitungan jumlah sel piknosis dan nekrosis

Dari gambar 4.4 diatas dapat dilihat bahwa aplikasi ini merupakan sebuah perkembangan teknologi kedokteran islam abad ke-7 hingga ke-9 oleh para ilmuan muslim disaat itu, yang banyak memadukan teknik medis dari beragam peradaban dalam penemuan cara pengobatan yang lebih baik dan maju, yang kemudian dikembangkan secara terus menerus sehingga dapat ditemukannya pemaduan ilmu medis dengan teknologi komputerisasi yang semakin berkembang dimasyarakat era ini yaitu Aplikasi penghitungan jumlah sel piknosis dan nekrosis.

\section{PEMBAHASAN}

Kesulitan yang dihadapi dalam menentukan sel piknosis dan nekrosis secara manual terletak pada tipisnya perbedaan mikroskopik dari masing masing sel piknosis dan nekrosis, dimana pada sel nekrosis terjadi perubahan pada intinya yaitu hilangnya gambaran khromatin, inti menjadi keriput, tidak vasikuler lagi, inti tampak lebih padat, warnanya gelap hitam (piknosis), inti terbagi atas fragmen-fragmen, robek (karioreksis), inti tidak lagi mengambil warna banyak karena itu pucat tidak nyata (kariolisis) (Himawan, 1992). Akan tetapi selama masih bisa dijadikan citra, maka tipisnya perbedaan tersebut dapat diatasi, karena satu citra dengan citra yang lainnya memiliki ciri tertentu yaitu terletak pada matrik pembentuk citra tersebut yang nilainya dimulai dari 0 hingga 225.

Proses thresholding ini pada dasarnya adalah proses penggubahan kuantisasi pada citra. Untuk mendapatkan hasil segmentasi yang bagus, beberapa operasi perbaikan kualitas citra dilakukan terlabih dahulu untuk mempertajam batas antara objek dengan latar belakangnya yaitu pengubahan citra dalam bantuk biner. 
Citra biner yaitu citra yang memiliki dua nilai tingkat keabuan, yaitu : hitam dan putih bergantung apakah nilai piksel asli tersebut lebih besar atau lebih kecil dari nilai $\mathrm{T}$. Piksel akan diubah menjadi putih (piknosis) jika nilai tingkat keabuannya lebih kecil daripada T, dan akan diubah menjadi hitam (Nekrosis) jika nilai tingkat keabuannya lebih besar atau sama dengan $\mathrm{T}$.

Thresholding merupakan salah satu teknik segmentasi yang baik digunakan untuk citra dengan perbedaan nilai intensitas yang signifikan antara latar belakang dan objek utama (Katz,2000).

Dalam pelaksanaannya thresholding membutuhkan suatu nilai yang digunakan sebagai nilai pembatas antara objek utama dengan latar belakang, dan nilai tersebut dinamakan dengan threshold. Nilai Threshold digunakan untuk mempartisi citra dengan mengatur nilai intensitas semua piksel yang lebih besar dari nilai threshold $\mathrm{T}$ sebagai latar depan dan yang lebih kecil dari nilai threshold $\mathrm{T}$ sebagai latar belakang. Biasanya pengaturan nilai threshold dilakukan berdasarkan histogram yaitu prosentase warna hitam dan putih yaitu warna keabuan.

Dari ciri warna keabuan, sel piknosis dan nekrosis memiliki nilai intensitas keabuan yang hampir sama, tetapi sel piknosis memiliki intensistas warna keabuan yang lebih terang dibandingkan sel nekrosis walaupun sama sama gelap pekat. Sehingga saat nilai threshold semakin di kurangi, sel-sel piknosis akan menghilang dari palet/kanvas citra dengan kata lain sel akan berubah menjadi warna yang semakin terang atau terarah ke warna putih dan tersisalah sel-sel nekrosis. Dan sebaliknya saat nilai threshold semakin ditambah, maka yang terjadi adalah sel sama-sama, terbaca sebagai sel nekrosis dan bisa dikatakan menghilang dari palet/ kanvas citra menghitam. Dalam artian jika $\mathrm{T}<0.5=0$ (Putih), dan $\mathrm{T} \geq 0.5=1$ (hitam). Maka dari itu untuk mentukan nilai threshold yang tepat harus berhati hati, agar citra sel piknosis tidak terbaca nekrosis dan begitu pula sel nekrosis tidak terbaca sebagai piknosis.

\section{KESIMPULAN}

Berdasarkan hasil analisis citra ginjal untuk identifikasi sel piknosis dan nekrosis, diperoleh nilai threshold yang tepat untuk menghitung jumlah sel piknosis dan nekrosis yaitu 0,67 melalui tahapan pengolahan citra yang meliputi cropping, pengubahan warna menjadi grayscale, dan penerapan filter Gaussian. Dan ketepatan aplikasi yang dihasilkan yaitu kurang lebih 90\% dari masing masing sel (piknosis dan nekrosis), sehingga aplikasi ini layak digunakan untuk menghitung jumlah sel piknosis dan nekrosis.

\section{DAFTAR PUSTAKA}

Price, S.A \& L.M Wilson. 1995. Patofisiologi Konsep Klinis. Edisi 4. Alih Bahasa Peter Anugerah. Jakarta : EGC. 
Usman, ahmad. 2005. Pengolahan Citra Digital dengan Teknik Pemrograman. Graha Ilmu: Yogyakarta. 